\title{
Effects of Materials and The Age of Roofing Sheets on The Quality of Harvested Rainwater in Totoro Abeokuta, Ogun State Nigeria.
}

\author{
Osunkiyesi Ayodele A., OlawunmiMuibat O.,SoyemiOlufemi S., \\ Okibe Obed D. \\ Department of Science Laboratory Technology (Chemistry Unit) Moshood Abiola Polytechnic, Abeokuta, Ogun \\ State
}

\begin{abstract}
This study was carried out to determine the effects of materials and the age of roofing sheets on the quality of harvested rainwater in Totoro Abeokuta area of Ogun State Nigeria, between the months of June and August 2015. The rainwater samples were collected carefully, stored properly and then taken to the laboratory for physicochemical analysis which was conducted in accordance with standard procedures. The physicochemical analysis results showed a temperature range of $26.75 \circ \mathrm{C}-27.70 \mathrm{oC}, \mathrm{pH}$ range of $5.18-7.08$, Dissolved Oxygen range of $5.46-7.43 \mathrm{mg} / \mathrm{L}$, conductivity range of $5.77-88.30 \mu \mathrm{S} / \mathrm{cm}$, color of $5.00 \mathrm{TCU}$, turbidity range of $0.41-2.97 \mathrm{mg} / \mathrm{L}$, total solids range of $6.55-82.70 \mathrm{mg} / \mathrm{L}$, total suspended solids range of 4.25 $43.30 \mathrm{mg} / \mathrm{L}$ and total dissolved solids range of $2.30-39.40 \mathrm{mg} / \mathrm{L}$. All these physical quantities had concentration within the recommended guidelines of the World Health Organization except the $\mathrm{pH}$ of some samples which fell below the lower limit of 6.5 and are thus more acidic. The chemical qualities of Acidity ranged between 3.10$26.50 \mathrm{mg} / \mathrm{L}$, alkalinity $3.00-8.10 \mathrm{mg} / \mathrm{L}$, total hardness $5.24-47.10 \mathrm{~m} / \mathrm{L}$, calcium hardness $1.21-37.10 \mathrm{mg} / \mathrm{L}$, magnesium hardness $4.03-14.50 \mathrm{~m} / \mathrm{L}$, chloride $13.25-30.02 \mathrm{mg} / \mathrm{L}$, nitrate $1.66-5.17 \mathrm{mg} / \mathrm{L}$, nitrite having highest value of $0.072 \mathrm{mg} / \mathrm{L}$ while sulphate and phosphate had $15.50 \mathrm{mg} / \mathrm{L}$ and $1.66 \mathrm{mg} / \mathrm{L}$ respectively and some are below detection limit. Elemental qualities ranged between $0.01 \mathrm{mg} / \mathrm{L}$ for Chromium and $0.89 \mathrm{mg} / \mathrm{L}$ for manganese. All these values are seen to be below the limits stipulated by the WHO as a guide for potable water. Although, the values obtained for aged roofing sheets were more than those obtained for new roofing sheets and those for asbestos were more than those for the corrugated iron sheets in some parameters. It was found in this investigation that the material from which the roof is made affects the rainwater quality as a contrast was seen between the concentrations of the roofing sheets samples and the control samples. Also, the age of the roofing sheets adversely affects the water quality. This can be attributed to the deterioration of aged sheets leading to the release of the embedded chemicals, metals and contaminants into the water as they fall and strike it.
\end{abstract}

Keywords: chemical analysis, elemental analysis, harvested rainwater, physicochemical analysis, roofing sheets

\section{Introduction}

Water, one of the many natural resources on earth is widely regarded as the most important of them all. There is hardly any life's process or activity that does not require the use of water either directly or indirectly. Water is very important in carrying out farming activities aimed at growing crops for food production. It is also used in household activities such as cooking, washing, cleaning, bathing and for drinking. Activities of most industries and manufacturing firms and organization cannot be possible without the use of this very important natural resource. Thanks to mother earth, this water can be sourced for or gotten from different means including streams, rivers, wells and also rainfall.

The various sources of water in our communities are now being largely affected and polluted by almost all human activities and some natural occurrences. Some of the human activities that can cause pollution of these water sources are; mining, improper waste disposal, fertilizer and pesticides application, industrial wastes etc. Erosion and volcanic eruption are some of the natural occurrences that cause water pollution as they affect both surface and ground water. All these activities and occurrences pose threat to sources of potable water. Lack of effective pollution control compromises the quality of water posing potential health hazards, increasing treatment and maintenance cost and affecting inland, estuarine and coastal aquatic ecosystem ${ }^{[1]}$.

Other sources of threat to source of potable water are urbanization, rapid industrialization and high population growth. These occurrences and situations lead to the release of more water into the environment- air, water, land etc. These wastes directly or indirectly enter into the water ways and hamper its portability.

The issue of rainwater harvesting is now a widely used technique for the provision of both potable and non-potable supply of water as it is culturally regarded as the least vulnerable of all the water sources. Rainwater harvesting is also widely used in developing countries where the public or private water mains are insufficient to 
meet the ever growing needs of the society or populace. Rainwater can be a valuable resource and can be quite safe for drinking when harvested and stored in a properly installed and maintained water catchment system or equipment. A typical rainwater harvesting system comprises of components for collection and transporting water through pipes or drains, filtration of the harvested water and suitable tanks or reservoirs for the storage of the harvested water.

Among the various catchments for the harvesting or collection of rainwater, roof catchment seems to be the most common both in rural areas where rainwater harvesting is still the only source of potable water for domestic use and in urban areas where it is mostly a supplementary source of water due to the inefficiency of the water networks. This is because the inhabitants use existing roofs of their houses in order to avoid incurring additional costs. The quality and amount of water collected depends on the area and type of roofing material used.

Roofs provide an ideal catchment surface for harvesting rainwater provided they are clean. They are usually made of a variety of materials and most, with the exception of those made from grass (thatch roof) are suitable as rainwater catchment surface. Examples of roofing materials are corrugated iron sheet, corrugated plastic, asbestos- cement sheets, concrete, tiles, galvanized iron, metal sheets, anodized aluminum and clay. The most commonly used roofing materials in Nigeria and in the study areas are galvanized iron, aluminum and asbestos.

The quality of drinking water is a powerful environmental determinant of health. Drinking water quality management has been a key pillar of primary prevention of diseases for over one and a half centuries and it continues to be the foundation for the prevention and control of waterborne diseases ${ }^{[2]}$. In the past, it was believed that rainwater was pure and could be consumed prior to purification and treatment. This may be true in some areas and location that are unpolluted due to high level of industrialization, urbanization and over population; rainwater collected in many locations however contains large number of chemical and nonchemical impurities.

Contamination of harvested rainwater by chemical pollutants may arise from a variety of materials or substances which it comes in contact with starting from the atmosphere. Rainwater could dissolve gases and wash off chemicals from contacting dust particles and roof materials. It could also dissolve metals. Separation of chemicals from the walls of storage tanks is also possible. This calls for a need for proper examination and testing of water before it can be used for domestic purposes especially drinking. Therefore a study of the effect of roofing materials on the physical and chemical qualities of rainwater harvested for domestic uses is necessary and also examination of the effect of the age of these roofing materials on the harvested rainwater's qualities are to be determined.

\subsection{Description Of Study Area}

\section{Materials And Methods}

The study area of this investigation is Totoro in Abeokuta north Local Government Area of Ogun State, with an area of about $808 \mathrm{~km}^{2}$ and a population of about 201,329 at the 2006 census ${ }^{[3]}$. This study area was chosen due to its lack of industrial activities as majority of the houses there are for residential, clinical, religious and educational purposes. Apart from a few bakeries present in the area, there are no other industrial activities. Also due to the high reliance of the inhabitants on rainwater, due to lack of consistent potable and reliable public or private water mains, the community relies extensively on rainwater harvesting because it is free, accessible during the rainy seasons and culturally believed to be safe for drinking and other domestic activities.

\subsection{Method Of Sampling And Collection Of Rainwater Samples}

A random sampling technique or method was employed in selecting the sampled houses. The first field work was to identify houses with the choice roofing material (new and aged asbestos sheets and new and aged corrugated iron sheets) within the study area and then the houses from whose roofs the rainwater samples will be harvested was chosen randomly.

The samples were collected between the months of June and August when the rains were peak. Care was taken to ensure that no accidental contamination occurred during sample collection and storage. The rainwater samples were collected into containers and stored in bottles which were previously washed with liquid soap having no fragrance or scent as this could affect one of the physical properties (odor) of the samples. These containers and bottles were then rinsed with sterile (double distilled-de-ionized) water and left to drain to dryness prior to being used for collection.

During collection, first flush from the roofs was avoided and not collected as this could contain extremely high amount of contaminants and dirt deposited from the atmosphere. The control sample was collected directly from the atmosphere avoiding any contact. The temperature and $\mathrm{pH}$ of the samples were obtained at the spot of collection before the samples were stored in the refrigerator at a temperature of $4^{\circ} \mathrm{C}$ prior to being taken to the laboratory for analysis. 


\subsection{Physicochemical Analysis}

The physicochemical parameters were determined using standard methods of water analysis ${ }^{[4]}$ which included suspended solids, total solids dissolved solids, volatile solids, turbidity, $\mathrm{pH}$, acidity, and alkalinity.

\subsection{Instrumental Analysis Of The Sample}

$100 \mathrm{ml}$ of each of the sample was measured into a $250 \mathrm{ml}$ Erlenmeyer flask and acidified with $2 \mathrm{M}$ HNO3. The mixture was swirl to mix properly, evaporated to dry on a steam bath and cooled. $25 \mathrm{ml}$ concentrated HNO3 concentrated HNO3 was added to the cooled residual bath. The flask was placed in a hot plate and the acid evaporated to small volume taking care that there was no spattering in the process. $25 \mathrm{ml}$ concentrated $\mathrm{HNO} 3$ and $10 \mathrm{ml} \mathrm{H} 2 \mathrm{O}$ was added repeatedly each time completed by repeating the above procedure, and the residue in the flask was white. The following metals were analyzed using Bulk 110 model of Atomic Absorption Spectrophotometer: Iron, Chromium, Manganese, Copper, Aluminum and Zinc.

\section{Results And Discussion}

The Organoleptic and physical analysis conducted on the various harvested rainwater samples provided results for temperature, color, odor, conductivity, dissolved oxygen, total suspended solid, total dissolved solid and total solid which are shown in the table 1 and table 2 shows the results of analysis of some chemical properties of these water samples while the results obtained from the elemental analysis carried out on the water samples are as shown in the table 3.

Table 1 presents the physical parameters of the water samples. The result showed that the temperature of the samples ranged between $26.75^{\circ} \mathrm{C}$ and $27.70^{\circ} \mathrm{C}$ with the temperature of asbestos roofing sheets being more than that of the corrugated iron sheets. However, these temperatures values fell within the range of $20^{\circ} \mathrm{C}$ to $32^{\circ} \mathrm{C}$ as stipulated by the $\mathrm{WHO}^{[5]}$. All samples had similar color with 5.0TCU value which corresponds with the limit of $15 \mathrm{TCU}$ set by the $\mathrm{WHO}^{[5]}$. Average turbidity values for new and aged asbestos sheets were 2.97NTU and $1.50 \mathrm{NTU}$ respectively and $0.41 \mathrm{NTU}$ and $0.62 \mathrm{NTU}$ for new and aged CIS respectively. That for the control samples was $0.53 \mathrm{NTU}$. The high average turbidity value for asbestos sheets can be attributed to the high amount of suspended solids present in it. This high turbidity reduces light penetrating ability in the samples and leads to a higher temperature as particles tend to absorb heat. However, the average turbidity values conformed to the limit of 5.0NTU stipulated by the $\mathrm{WHO}^{[5]}$.

Dissolved oxygen values for new and aged asbestos, new and aged CIS are $5.74 \mathrm{mg} / \mathrm{L}, 6.985 \mathrm{mg} / \mathrm{L}$, $7.425 \mathrm{mg} / \mathrm{L}$ and $6.11 \mathrm{mg} / \mathrm{L}$ respectively. These values were similar to that of the control samples $5.46 \mathrm{mg} / \mathrm{L}$ which suggests that the roof material had little or no effect on dissolved oxygen content of water samples. According to the $\mathrm{WHO}^{[6]}$ no health based guideline value is recommended.

New and aged asbestos, new and aged CIS and the control samples had electrical conductivity values of $87.90 \mu \mathrm{S} / \mathrm{cm}, 88.30 \mu \mathrm{S} / \mathrm{cm}, 18.20 \mu \mathrm{S} / \mathrm{cm}, 9.25 \mu \mathrm{S} / \mathrm{cm}, 5.77 \mu \mathrm{S} / \mathrm{cm}$ respectively. The high conductivity of the samples from asbestos sheet can be attributed to the high amount of dissolved solids in it and conductivity is a good indicator of the presence or absence of conductivity ions. This is also similar to the results obtained by Eruola et al ${ }^{[7]}$ in OkeLantoro Abeokuta. However, these conductivity values all fall below the limit of $1000 \mu \mathrm{S} / \mathrm{cm}$ set by the WHO ${ }^{[8]}$.

The average total dissolved solids value of samples are $37.71 \mathrm{mg} / \mathrm{L}, 39.40 \mathrm{mg} / \mathrm{L}, 7.75 \mathrm{mg} / \mathrm{L}, 6.85 \mathrm{mg} / \mathrm{L}$ and $2.30 \mathrm{mg} / \mathrm{L}$ for new and aged asbestos, new and aged CIS and the control respectively. The result obtained shows that the TDS values for asbestos is higher than that of CIS and this corresponds with the result of study carried out by Bada et al., ${ }^{[9]}$ in Abeokuta- a high range $9.67 \mathrm{mg} / \mathrm{L}$ to $71.00 \mathrm{mg} / \mathrm{L}$ for asbestos. TDS has a huge effect on other characteristics of water samples such as the temperature, turbidity and electrical conductivity. However, all these values are below the limit of $500 \mathrm{mg} / \mathrm{L}$ set by the $\mathrm{WHO}^{[8]}$.

Average total suspended solids value of samples are $42.61 \mathrm{mg} / \mathrm{L}, 43.30 \mathrm{mg} / \mathrm{L}, 5.70 \mathrm{mg} / \mathrm{L}, 4.00 \mathrm{mg} / \mathrm{L}$ and $4.25 \mathrm{mg} / \mathrm{L}$ for new and aged asbestos, new and aged CIS and the control respectively. The result obtained also shows that TSS values for asbestos samples are much higher than that for CIS. The high value of TSS in the control can be attributed to suspended particles such as dust in the atmosphere. TSS also affects other characteristics such as turbidity and conductivity (the higher the TSS, the higher the turbidity and conductivity).

The total solids value for samples are $80.42 \mathrm{mg} / \mathrm{L}, 82.70 \mathrm{mg} / \mathrm{L}, 13.45 \mathrm{mg} / \mathrm{L}, 10.85 \mathrm{mg} / \mathrm{L}$ and $6.55 \mathrm{mg} / \mathrm{L}$ for new and aged asbestos, new and aged CIS and the control respectively. The total solids value for asbestos is also seen to be higher than that for CIS and this value has a significant effect on the turbidity, conductivity and temperature of the samples.

$\mathrm{pH}$ values of $6.715 \mathrm{mg} / \mathrm{L}, 7.075 \mathrm{mg} / \mathrm{L}, 6.47 \mathrm{mg} / \mathrm{L}, 6.33 \mathrm{mg} / \mathrm{L}$ and $5.18 \mathrm{mg} / \mathrm{L}$ was obtained for new and aged asbestos, new and aged CIS and the control respectively. The $\mathrm{pH}$ of a sample indicates if the sample is acidic or alkaline. The $\mathrm{pH}$ of new and aged asbestos sheet fell within the range of 6.5 to $8.5 \mathrm{mg} / \mathrm{L}$ set by the WHO ${ }^{[5]}$ while that of new and aged CIS and the control were below $6.5 \mathrm{mg} / \mathrm{L}$ meaning that these samples are 
more acidic. The acidity of the samples can be attributed to the dissolution of atmospheric acidic oxides in the water.

Table 2 presents the chemical parameters. The mean values of the chemical parameters shown indicates that the average total hardness of samples were $39.20 \mathrm{mg} / \mathrm{L}, 47.10 \mathrm{mg} / \mathrm{L}, 28.00 \mathrm{mg} / \mathrm{L}, 5.235 \mathrm{mg} / \mathrm{L}$ and $18.50 \mathrm{mg} / \mathrm{L}$ for new and aged asbestos, new and aged CIS and the control respectively. The hardness of samples of asbestos sheet is seen to be higher than that of CIS this can be attributed to the higher amount of total solids in the asbestos samples. However, these values are seen to be less than that obtained by Olaoye and Olaniyan ${ }^{[2]}$ in their activity conducted in Oyo State in which they got a value of $84 \mathrm{mg} / \mathrm{L}$ to $86 \mathrm{mg} / \mathrm{L}$. The hardness values of samples have significant effect on its mineral content and alkalinity. These values are considered safe as they fall below the range of $100-300 \mathrm{mg} / \mathrm{L}$ stipulated by the $\mathrm{WHO}^{[5]}$.

Calcium hardness of samples had average values of $29.10 \mathrm{mg} / \mathrm{L}, 37.10 \mathrm{mg} / \mathrm{L}, 13.50 \mathrm{mg} / \mathrm{L}, 1.21 \mathrm{mg} / \mathrm{L}$ and $8.00 \mathrm{mg} / \mathrm{L}$ for new and aged asbestos, new and aged CIS and the control respectively. These values also showed that hardness of asbestos is higher than hardness of CIS. However, these values are also safe as they fall below the limit of $75 \mathrm{mg} / \mathrm{L}$ set by $\mathrm{WHO}^{[8]}$.

Magnesium hardness of new and aged asbestos, new and aged CIS and the control has values of $10.10 \mathrm{mg} / \mathrm{L}, 10.00 \mathrm{mg} / \mathrm{L}, 14.50 \mathrm{mg} / \mathrm{L}, 4.025 \mathrm{mg} / \mathrm{L}$ and $10.50 \mathrm{mg} / \mathrm{L}$ respectively. These values were also less than those obtained by Olaoye and Olaniyan, ${ }^{[2]}$ in their activity in Oyo State in which a value of $30.8 \mathrm{mg} / \mathrm{L}$ to $38.6 \mathrm{mg} / \mathrm{L}$ was obtained. These values are also regarded as safe as they are less than the limit of $50 \mathrm{mg} / \mathrm{L}$ stipulated by the $\mathrm{WHO}^{[5]}$.

Average chloride values of $30.02 \mathrm{mg} / \mathrm{L}, 18.10 \mathrm{mg} / \mathrm{L}, 22.25 \mathrm{mg} / \mathrm{L}, 13.25 \mathrm{mg} / \mathrm{L}$ and $14.50 \mathrm{mg} / \mathrm{L}$ were obtained for new and aged asbestos, new and aged CIS and the control respectively. These values were found to be much less than the $90.0 \mathrm{mg} / \mathrm{L}$ obtained by Olaoye and Olaniyan, ${ }^{[2]}$ in Oyo state which is less than the maximum of $250 \mathrm{mg} / \mathrm{L}$ set by the $\mathrm{WHO}^{[8]}$ along with the result of this investigation. The significance of average chloride content is its effect on salinity. The higher the chloride content, the higher the salinity of water samples.

Nitrate content of samples had average values of $5.17 \mathrm{mg} / \mathrm{L}, 2.33 \mathrm{mg} / \mathrm{L}, 1.66 \mathrm{mg} / \mathrm{L}, 3.01 \mathrm{mg} / \mathrm{L}$ and $1.95 \mathrm{mg} / \mathrm{L}$ for new and aged asbestos, new and aged CIS and the control respectively. These values are also much less than the range of $31.9 \mathrm{mg} / \mathrm{L}$ to $39 \mathrm{mg} / \mathrm{L}$ obtained by Olaoye and Olaniyan, ${ }^{[2]}$ in their investigation. The significance of nitrate is that it affects the oxygen carrying ability of blood- a high nitrate value results in a reduced carriage of oxygen by the blood. All the values obtained in this investigation and that of Olaoye and Olaniyan ${ }^{[2]}$ however were below the limit of $50 \mathrm{mg} / \mathrm{L}$ set by the $\mathrm{WHO}^{[5]}$.

Nitrite, the reduced form of nitrate, had values of $0.072 \mathrm{mg} / \mathrm{L}, 0.043 \mathrm{mg} / \mathrm{L}$ for new and aged asbestos respectively. Nitrite values for new CIS was below detection limit (BDL) while that for aged CIS and the control are $0.023 \mathrm{mg} / \mathrm{L}$ and $0.002 \mathrm{mg} / \mathrm{L}$ respectively. These values are all safe as they fall below the limit of $0.2 \mathrm{mg} / \mathrm{L}$ set by the $\mathrm{WHO}^{[5]}$. The significance and effect of nitrite is similar to the effect of nitrate.

The result obtained for sulfate content of samples from new and aged asbestos and new CIS are $6.00 \mathrm{mg} / \mathrm{L}, 15.00 \mathrm{mg} / \mathrm{L}$ and $15.50 \mathrm{mg} / \mathrm{L}$ respectively. That for aged CIS was below detection limit while that for the control sample was $1.00 \mathrm{mg} / \mathrm{L}$. Though these values are much more than the value for the control sample, they are still regarded as safe as they are below the limit of $100 \mathrm{mg} / \mathrm{L}$ set by the WHO ${ }^{[8]}$. The significance of sulfate is that high intake of it can lead to a high tendency of diarrhea infection.

The phosphate content for new and aged asbestos, new and aged CIS and the control are $1.04 \mathrm{mg} / \mathrm{L}$, $1.66 \mathrm{mg} / \mathrm{L}, 0.68 \mathrm{mg} / \mathrm{L}, 1.40 \mathrm{mg} / \mathrm{L}$ and $0.15 \mathrm{mg} / \mathrm{L}$ respectively. The values for each sample is seen to be similar or close to that of the control suggesting that phosphate content of various roof material is considerably okay as there is no known limit set by the WHO. A high amount of phosphate has only a slight temporal effect (interference with digestion) in the body of humans.

Acidity- a measure of the samples' ability to neutralize concentrated base had average values of $9.00 \mathrm{mg} / \mathrm{L}, 3.10 \mathrm{mg} / \mathrm{L}, 13.00 \mathrm{mg} / \mathrm{L}, 11.00 \mathrm{mg} / \mathrm{L}$ and $26.50 \mathrm{mg} / \mathrm{L}$ for new and aged asbestos, new and aged CIS and the control respectively. The acidity of the samples can be attributed to the dissolution of atmospheric acidic oxides in the water as it falls from the sky. Water with high acidity is usually very corrosive and since there's no known standard set by the WHO, acidity can be said to be of mild effect.

Alkalinity- a measure of the samples' ability to neutralize strong acids has average values of $8.10 \mathrm{mg} / \mathrm{L}$, $12.05 \mathrm{mg} / \mathrm{L}, 3.00 \mathrm{mg} / \mathrm{L}, 4.00 \mathrm{mg} / \mathrm{L}$ and $3.00 \mathrm{mg} / \mathrm{L}$ for new and aged asbestos, new and aged CIS and the control respectively. Alkalinity is related to hardness and this explains why the alkalinity of asbestos samples is higher than that of CIS samples just as the hardness of asbestos samples is higher than that of CIS samples. There is also no known limit set by the WHO for alkalinity.

Table 3 presents the result for Iron content of the samples as $0.01 \mathrm{mg} / \mathrm{L}$ for new asbestos while that for aged asbestos, new and aged CIS and the control were found to be below detection limit. Eletta and Oyeyipo, ${ }^{[10]}$ in their investigation carried out in Ilorin, Kwara state got 1.02 to $3.01 \mathrm{mg} / \mathrm{L}$ and 2.36 to $4.5 \mathrm{mg} / \mathrm{L}$ for Iron content of new and aged CIS. These values are seen to be much higher than that obtained in this investigation 
and the $\mathrm{WHO}^{[5]}$ standard of $0.3 \mathrm{mg} / \mathrm{L}$. Iron play an important role in aiding the transportation of oxygen in the blood and it has no severe hazard when present in large amounts.

The average values for chromium content of samples were $0.03 \mathrm{mg} / \mathrm{L}, 0.04 \mathrm{mg} / \mathrm{L}, 0.05 \mathrm{mg} / \mathrm{L}, 0.01 \mathrm{mg} / \mathrm{L}$ and $0.02 \mathrm{mg} / \mathrm{L}$ for new and aged asbestos, new and aged CIS and the control respectively. These values were found to be consistent with the limit of $0.05 \mathrm{mg} / \mathrm{L}$ set by the WHO ${ }^{[5]}$. However, high amounts of chromium in drinking water can be attributed to cancer and tumor formation and thus should be avoided.

The average values for the manganese content of new and aged asbestos and new CIS were $0.71 \mathrm{mg} / \mathrm{L}$, $0.75 \mathrm{mg} / \mathrm{L}$ and $0.89 \mathrm{ng} / \mathrm{L}$ respectively. That for aged CIS was below detection limit while that for the control was $0.15 \mathrm{mg} / \mathrm{L}$. In the investigation carried out by Joanne, ${ }^{[1]}$ in Nairobi, Kenya, the Manganese content of samples had a value of $0.06 \mathrm{mg} / \mathrm{L}$ which is less than that obtained for same samples in this investigation and together with the result of the control fall below the recommended guidelines of $0.4 \mathrm{mg} / \mathrm{L}$ by the WHO ${ }^{[5]}$. The result of samples in this investigation is however higher than the recommendation and thus may have a suggestive adverse effects on the water quality which may lead to a bitter metallic taste and odor but no significant danger to the health. However, its low content in these samples did not pose significant effect on its properties.

The average copper content of samples are $0.22 \mathrm{mg} / \mathrm{L}, 0.3 \mathrm{mg} / \mathrm{L}, 0.29 \mathrm{mg} / \mathrm{L}, 0.22 \mathrm{mg} / \mathrm{L}$ and $0.20 \mathrm{mg} / \mathrm{L}$ for new and aged asbestos, new and aged CIS and the control respectively. Eletta and Oyeyipo, ${ }^{[10]}$ in their investigation in Kwara state got the following range of values $0.02 \mathrm{mg} / \mathrm{L}$ to $0.10 \mathrm{mg} / \mathrm{L}$ and $0.11 \mathrm{mg} / \mathrm{L}$ to $0.33 \mathrm{mg} / \mathrm{L}$ for new and aged CIS respectively while Joanne, ${ }^{[1]}$ got values below detection limit result for CIS in Kenya. The values obtained by these investigators are found to be similar to that obtained in this investigation and all fall below the limit of $2.0 \mathrm{mg} / \mathrm{L}$ set by the WHO ${ }^{[5]}$. However, a high copper content of drinking water is associated with gastrointestinal diseases and long intakes results in liver or kidney damage.

This investigation found Aluminum content of new and aged asbestos and new CIS to be $0.07 \mathrm{mg} / \mathrm{L}$, $0.15 \mathrm{mg} / \mathrm{L}$ and $0.13 \mathrm{mg} / \mathrm{L}$ respectively while that for aged CIS and the control were below detection limits and $0.07 \mathrm{mg} / \mathrm{L}$ respectively. These values all correspond with the limit of $0.1 \mathrm{mg} / \mathrm{L}$ set by the WHO ${ }^{[11]}$ except the values of aged asbestos and new CIS which are slightly above. Very high values of aluminum are associated with a mental disorder known ad dementia- an inability to think and thus should be avoided.

This investigation found Zinc content of new and aged asbestos and new CIS to be $0.28 \mathrm{mg} / \mathrm{L}$, $0.08 \mathrm{mg} / \mathrm{L}$ and $0.35 \mathrm{mg} / \mathrm{L}$ respectively while that for aged CIS and the control were below detection limit and $0.13 \mathrm{mg} / \mathrm{L}$ respectively. These values are found to be less than those obtained by Eletta and Oyeyipo ${ }^{[10]}$ in their investigation on new and aged CIS (2.03 to $3.43 \mathrm{mg} / \mathrm{L}$ and 2.39 to $3.96 \mathrm{mg} / \mathrm{L}$ respectively) but correspond with the values obtained by Joanne, ${ }^{[1]}$ on CIS $(0.30 \mathrm{mg} / \mathrm{L})$. The results obtained in this investigation and that of Joanne ${ }^{[1]}$ are found to correspond with the limit of $3.0 \mathrm{mg} / \mathrm{L}$ stipulated by the WHO ${ }^{[5]}$ while that of Eletta and Oyeyipo $^{[10]}$ are above and thus unsafe for drinking. Zinc in water is significant in that it is required for good working of the immune system, diarrhea treatment, common cold treatment and wound healing but extreme amounts have adverse effects on the health.

\section{Conclusion}

All the physical parameters of all the harvested rainwater samples analyzed in this investigation conformed with the recommended guidelines stipulated by the WHO, though the values of some parameters (total dissolved solids, total suspended solids, total solids) of asbestos sheet was much higher than the values of corrugated iron sheets. The chemical parameters analyzed also conformed with the guidelines established by the WHO except the $\mathrm{pH}$ of some samples, whose values fell below the stipulated lower limit of 6.5 and thus are more acidic. Most of the chemical parameters also followed the pattern of the physical characteristics in which the values for asbestos was higher than those of CIS.

The elemental parameters of samples investigated followed no regular patter as the values for CIS was more than the values obtained for asbestos in some parameters while the values for asbestos was more than the values obtained for CIS in some parameters. Also, it was found in some of the parameters of the samples investigated that the value or content was more in the aged than in the new roofing sheet. This can be attributed to the deterioration of aged sheet leading to the release of these chemicals and contaminants into the water as they fall and strike it. And in some, the new had more content than the aged.

In a comparison of the result of this investigation and those of the literature review, it can be seen that the rainwater in this study area is safer when compared to the study areas of the review as the values and contaminants in the rainwater from this study area were much less than those of the literature review. Seeing that all the samples contain one contaminant or the other, all samples must undergo some level of purification before they can be used for drinking, cooking or any other domestic function. Water for drinking should undergo filtration, boiling, distillation and any other advantageous purification process before being drunk. However, filtration is enough for water required for other domestic purposes such as washing, bathing and cleaning. 
Table 1 - Result for organoleptic and physical analysis of harvested rainwater.

\begin{tabular}{|l|l|l|l|l|l|l|}
\hline Parameters & NA & AA & NCIS & ACIS & C & WHO \\
\hline Temperature ${ }^{0} \mathrm{C}$ & $27.70 \pm 0.00$ & $27.65 \pm 0.05$ & $27.65 \pm 0.05$ & $26.75 \pm 0.05$ & $26.80 \pm 0.00$ & $20-30$ \\
\hline Color TCU & $5.00 \pm 0.00$ & $5.00 \pm 0.00$ & $5.00 \pm 0.00$ & $5.00 \pm 0.00$ & $5.00 \pm 0.00$ & 15.00 \\
\hline Turbidity NTU & $2.97 \pm 0.01$ & $1.50 \pm 0.10$ & $0.41 \pm 0.00$ & $0.62 \pm 0.01$ & $0.53 \pm 0.31$ & 5.00 \\
\hline Dissolved Oxygen & $5.74 \pm 0.01$ & $6.985 \pm 0.005$ & $7.43 \pm 0.015$ & $6.11 \pm 0.01$ & $5.46 \pm 0.01$ & 4.00 \\
\hline Conductivity $\mu$ S/cm & $87.90 \pm 0.00$ & $88.30 \pm 0.10$ & $18.20 \pm 0.00$ & $9.25 \pm 0.05$ & $5.77 \pm 0.04$ & 1000 \\
\hline Total Dissolved Solids & $37.71 \pm 0.11$ & $39.40 \pm 0.10$ & $7.75 \pm 0.05$ & $6.85 \pm 0.05$ & $2.30 \pm 1.10$ & 500 \\
\hline Total Suspended Solid & $42.61 \pm 0.01$ & $43.30 \pm 0.20$ & $5.70 \pm 0.00$ & $4.00 \pm 0.10$ & $4.25 \pm 1.15$ & 500 \\
\hline Total Solids & $80.42 \pm 0.02$ & $82.70 \pm 0.10$ & $13.45 \pm 0.05$ & $10.85 \pm 0.05$ & $6.55 \pm 0.01$ & 1200 \\
\hline pH & $6.715 \pm 0.005$ & $7.08 \pm 0.005$ & $6.47 \pm 0.01$ & $6.33 \pm 0.01$ & $5.18 \pm 0.01$ & $6.5-8.5$ \\
\hline
\end{tabular}

N.B; NA- New Asbestos, AA- Aged Asbestos, NCIS- New Corrugated Iron Sheet, ACIS- Aged Corrugated Iron Sheet, C- Control Experiment, WHO- World Health Organization.

Values are in $\mathrm{mg} / \mathrm{L}$ except otherwise stated.

Table 2 - Result for chemical analysis of harvested rainwater.

\begin{tabular}{|c|c|c|c|c|c|c|}
\hline Parameters & NA & $\mathrm{AA}$ & NCIS & ACIS & $\mathrm{C}$ & WHO \\
\hline Acidity & $9.00 \pm 0.00$ & $3.10 \pm 0.10$ & $13.00 \pm 0.00$ & $11.00 \pm 0.00$ & $26.50 \pm 0.50$ & \\
\hline Alkalinity & $8.10 \pm 0.10$ & $12.05 \pm 0.10$ & $3.00 \pm 0.00$ & $4.00 \pm 0.00$ & $3.00 \pm 0.00$ & \\
\hline Total Hardness & $39.20 \pm 0.00$ & $47.10 \pm 0.10$ & $28.00 \pm 0.00$ & $5.24 \pm 0.165$ & $18.50 \pm 0.50$ & $100-300$ \\
\hline Calcium Hardness & $29.10 \pm 0.10$ & $37.10 \pm 0.1$ & $13.50 \pm 0.50$ & $1.21 \pm 0.19$ & $8.00 \pm 0.00$ & 75 \\
\hline Magnesium Hardness & $10.10 \pm 0.10$ & $10.00 \pm 0.20$ & $14.50 \pm 0.50$ & $4.03 \pm 0.025$ & $10.5 \pm 0.50$ & 50 \\
\hline Chloride & $30.02 \pm 0.02$ & $18.10 \pm 0.10$ & $22.25 \pm 0.05$ & $13.25 \pm 0.05$ & $14.5 \pm 0.50$ & 250 \\
\hline Nitrate & $5.17 \pm 0.01$ & $2.33 \pm 0.01$ & $1.66 \pm 0.005$ & $3.01 \pm 0.01$ & $1.95 \pm 0.005$ & 50 \\
\hline Nitrite & $0.072 \pm 0.001$ & $0.043 \pm 0.001$ & BDL & $0.023 \pm 0.001$ & $0.002 \pm 0.00$ & 0.2 \\
\hline Sulfate & $6.00 \pm 0.00$ & $15.00 \pm 0.00$ & $15.50 \pm 0.10$ & BDL & $1.0 \pm 0.00$ & 100 \\
\hline Phosphate & $1.04 \pm 0.005$ & $1.66 \pm 0.01$ & $0.68 \pm 0.01$ & $1.40 \pm 0.00$ & $0.15 \pm 0.005$ & \\
\hline
\end{tabular}

N.B; NA- New Asbestos, AA- Aged Asbestos, NCIS- New Corrugated Iron Sheet, ACIS- Aged Corrugated Iron Sheet, C- Control Experiment, WHO- World Health Organization.

Values are in $\mathrm{mg} / \mathrm{L}$ except otherwise stated.

Table 3 - Result for elemental analysis of harvested rainwater.

\begin{tabular}{|l|l|l|l|l|l|l|}
\hline Parameters & NA & AA & NCIS & ACIS & C & WHO \\
\hline Iron & $0.04 \pm 0.00$ & BDL & BDL & BDL & BDL & 0.30 \\
\hline Chromium & $0.03 \pm 0.01$ & $0.04 \pm 0.01$ & $0.05 \pm 0.005$ & $0.01 \pm 0.00$ & $0.02 \pm 0.005$ & 0.50 \\
\hline Manganese & $0.71 \pm 0.01$ & $0.75 \pm 0.05$ & $0.89 \pm 0.005$ & BDL & $0.15 \pm 0.05$ & 0.40 \\
\hline Copper & $0.22 \pm 0.01$ & $0.3 \pm 0.01$ & $0.29 \pm 0.01$ & $0.22 \pm 0.01$ & $0.2 \pm 0.10$ & 2.00 \\
\hline Aluminum & $0.07 \pm 0.01$ & $0.15 \pm 0.01$ & $0.13 \pm 0.00$ & BDL & $0.07 \pm 0.01$ & 0.10 \\
\hline Zinc & $0.28 \pm 0.00$ & $0.08 \pm 0.00$ & $0.35 \pm 0.01$ & BDL & $0.13 \pm 0.01$ & 3.00 \\
\hline
\end{tabular}

N.B; NA- New Asbestos, AA- Aged Asbestos, NCIS- New Corrugated Iron Sheet, ACIS- Aged Corrugated Iron Sheet, C- Control Experiment, WHO- World Health Organization.

Values are in $\mathrm{mg} / \mathrm{L}$ except otherwise stated.

\section{References}

[1] Joanne N. Gakungu. Qualitative assessment of Rainwater harvested from roof. International journal of soft computing and engineering (IJSCE) ISSN: 2231-2307, Volume 3, issue 4,2013,pg 263-266

[2] OlaoyeR.A., Olaniyan O.S. Quality of rainwater from different roof materials.International journal of engineering and technology. Volume 2 Number 8, August 2012. 2012.Pg 1413-1421

[3] Abeokuta North - https://en.m.wikipedia.org/wiki/Abeokuta_North. Date viewed 15 ${ }^{\text {th }}$ August 2015.

[4] Ademoroti C.M.A. Standard methods for water and effluents analysis (Foludex press Limited, Ibadan 1996) 79-171

[5] Guidelines for Drinking-water Quality, Fourth Edition; World Health Organisation; 2011

[6] Guidelines for Drinking-water Quality, Third Edition;Geneva World Health Organisation; 2008

[7] Eruola A.O., Ufoegbune G.C., Eruola A.O.,Awomeso J.A., Adeofun C.O.,Idowu O.A. and Sowunmi A. (2010). Qualitative and Quantitative assessment of Rainwater Harvetingfromrooftop catchment: case study of OkeLantoro community in Abeokuta South west Nigeria.European water publication 32, 47-56

[8] Guidelines for Drinking-water Quality, Third Edition; Geneva World Health Organisation;2004

[9] Bada B. S., olatunde K.A. and Bankole O.D. (2012). Chemical and Physical Properties of Harvested Rainwater from different Roofing sheets in Abeokuta. Ogun state. Hydrology for disaster Management special Publication of the Nigerian Association of Hydrological Sciences.Pg 173-179

[10] Eletta O.A.A. and Oyeyipo J.O (2008).Rain water harvesting: Effects of age of roof on Rainwater Quality. International Journal of Applied Chemistry. ISSN 0973-1792. Volume 4 Number 2. Pg 157-162

[11] World Health Organization Guidelines for drinking water quality, Geneva World Organization 2003. 